\title{
EXAMINATION AND EVALUATION OF PARENT'S PERCEPTIONS REGARDING THE GENDER OF PRE-SCHOOL TEACHERS
}

\author{
Menekşe V ${ }^{1} 凹$, Eren B ${ }^{2}$, Afşin Ö $^{3}$ \\ ${ }^{1}$ Director of Cevrimova Primary School, Turkey \\ ${ }^{2}$ Principal of Zübeyde Hanım Primary School, Turkey \\ ${ }^{3}$ Adem İlkilic Primary School Deputy Principal, Turkey
}

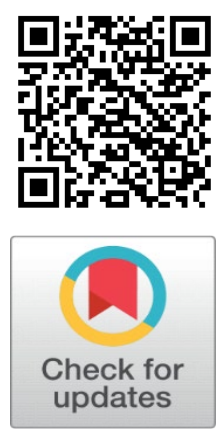

Received 19 July 2021

Accepted 2 August2021

Published 31 August 2021

\section{CorrespondingAuthor}

Menekşe V, mmyusuf2007@gmail.com DOI

10.29121/granthaalayah.v9.i8.2021. 4134

Funding: This research received no specific grant from any funding agency in the public, commercial, or not-for-profit sectors.

Copyright: (C) 2021 The Author(s). This is an open access article distributed under the terms of the Creative Commons Attribution License, which permits unrestricted use, distribution, and reproduction in any medium, provided the original author and source are credited.

\section{ABSTRACT}

For children aged 0-6, learning is the most intense period. A preschooler is the person most interested in taking care of her child's mother. Preschool education helps children think and express themselves. Studies (Melisa Korkmaz) have shown that children who receive pre-school education have higher school attendance rates and school success in their future academic life than children who do not receive pre-school education. In this context, the importance of the teacher in the pre-school period is undeniable. No matter how good the physical conditions of the school are, no matter how carefully the program is prepared, it is the teacher who is with the children all day and implements the program (Erișen, 2004).

In Turkish society, the care and responsibilities of the child are accepted as the mother's duty. As a result, the number of female teachers in pre-school education institutions is higher than the number of male teachers. Depending on this idea, the number of female teachers in pre-school education institutions is higher than male teachers.

According to TUIK 2014 data, the rate of male preschool teachers in Turkey is 5.34\%.

Fagan et al. (1996) brings more appropriate solutions to the conflicts between children and copes with aggressive behaviors in the classroom management of male preschool teachers.

In addition, today, reasons such as divorce, death and working conditions cause the mother to assume the role of a single parent. This situation reduces the possibility of a child growing up in such an environment to establish a close relationship with a male figure. Cameroon et al. (2001).

It is necessary to disseminate the view that men can take an active role in child care and education, to support male teachers who work or will work in pre-school education institutions, and to raise public awareness about the requirements of men in this field McBride and Rane (1997), Lamb et al. (2001).

In line with all this information, the problem of this research was determined as "parent perceptions of pre-school teachers regarding gender".

Keywords: Preschool Education, Teacher, Perception, Parent of The Student

\section{INTRODUCTION}

The pre-school teacher deals with the education of children who have not reached primary school age. Pre-school teachers can work in private education institutions approved by the Ministry of National Education (Ministry of National Education) and in public schools. Children younger than primary school age; $\mathrm{He}$ is a person who contributes to his emotional, social and intellectual development. Those who have made it their profession to teach a science, an art, a technique 
or a certain knowledge are called teachers. They are those who have obtained the authority to teach by completing the education required by the teaching profession or by gaining the qualifications. They are tasked with guiding and directing children, young people or adults to gain the desired learning and life in a public or private educational institution. Although there are many studies on teachers and preschool teachers, there are few studies on male preschool teachers in our country.

The sample of the study conducted by Yagbasan and Aksoy (2016)in order to determine the opinions of the teachers and parents practicing the profession about this profession and to try to understand by revealing the causes of the problem consists of 100 parents of children from 4 kindergartens selected by random sampling method based on the demographic profiles of the schools in the province of Elazig. Survey method based on survey method was used as data collection tool in the research. The result of the research showed that there is a significant prejudice against male teachers by parents.

\section{FINDINGS}

The study was carried out in schools with male teachers affiliated to the Ministry of National Education in the province of Batman. The study group consisted of 14 people in total, 7 parents whose children were taught by a male teacher and 7 parents whose children were taught by a female teacher.

Information about the study group is given in Table 1.

\begin{tabular}{|c|c|c|}
\hline Table 1 & & \\
\hline \multirow[t]{2}{*}{ Closeness to the Child } & Mother & Father \\
\hline & $\% 78,6$ & $\% 21,4$ \\
\hline \multirow[t]{2}{*}{ Level } & Primary School & Middle School \\
\hline & $\% 64,3$ & $\% 35,7$ \\
\hline \multirow[t]{2}{*}{ Profession Group } & Not working & Officer \\
\hline & $\% 41,5$ & $\% 58,5$ \\
\hline Working Teacher & $\% 50,0$ & $\% 50,0$ \\
\hline Gender & $\% 50,0$ & $\% 50,0$ \\
\hline
\end{tabular}

One of the research questions of the study is "What are the Perceptions of the Parents whose Children are Taught by a Female Teacher Regarding the Characteristics of Preschool Teachers?" was determined as. In order to answer this research question, interviews with parents whose child's teacher are a woman were analyzed, and the findings are given in Table 2.

\begin{tabular}{|lcc|}
\hline Table 2 & & \\
\hline Qualifications sought in a teacher & Love of children & 5,0 \\
& Tolerance & 3,0 \\
\hline & Democratic & 1.0 \\
& Idealist & 1,0 \\
\hline & Soft Temperament & 2,0 \\
\hline & Patience & 2,0 \\
\hline & Tidy & 1,0
\end{tabular}




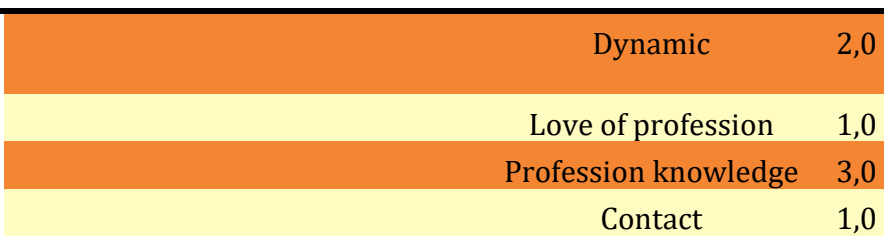

One of the research questions of the study is "What are the Perceptions of the Parents whose Children are Instructed by a Female Teacher towards Being a Male Preschool Teacher?" was determined as. In order to answer this research question, interviews with parents whose children are female teachers were analyzed, and the findings are given in Table 3

\section{Table 3}

$\begin{array}{ccc}\text { Opinions about the teacher being male } & \text { harsh temperament } & 2,0 \\ & \text { Fear of Abuse } & 3,0 \\ \text { indifference } & 3,0\end{array}$

One of the research questions of the study is "What are the Perceptions of the Parents whose Children are Instructed by a Male Teacher Regarding the Characteristics of Preschool Teachers?" was determined as. In order to answer this research question, interviews with parents whose children were taught by a male teacher were analyzed, and the findings are given in Table 4

\begin{tabular}{lcc}
\hline Table 4 & & \\
\hline Qualities sought in a teacher & Love of children & 4,0 \\
& Democratic & 1,0 \\
& Patience & 2,0 \\
& Soft Temperament & 2,0 \\
& Relating to & 2,0 \\
& Profession knowledge & 6,0 \\
& Effective Classroom Management & 4,0
\end{tabular}

One of the research questions of the study is "What are the Perceptions of Parents, whose children are taught by a male teacher, towards Preschool Teachers being male?" was determined as. In order to answer this research question, interviews with parents whose children were taught by a male teacher were analyzed, and the findings are given in Table 5.

\section{Table 5}

$\begin{array}{ccc}\text { Opinions about the teacher being male } & \text { Effective Classroom Management } & 5,0 \\ & \text { Continuity } & 1,0 \\ \text { Being a Model } & 2,0 \\ \text { Neutrality } & 2,0 \\ \text { Profession Information } & 3,0 \\ \text { Self-care } & 2,0 \\ \text { Patient } & 1,0\end{array}$




\section{DISCUSSION AND CONCLUSION}

In this section, the findings of the study, which was conducted to reveal the perspectives of parents against male teachers working in pre-school education institutions, were discussed and interpreted. In order to answer this research question, as a result of the answers received from the questions asked to the parents, the parents concluded that the preschool teacher should have personal characteristics (Love of children, tolerance, soft temperament, patience, order and communication) and Professional Characteristics (Democracy, professional knowledge, effective classroom management). has been reached. As a result of the answers received from the questions asked to the parents in order to answer this research question, the parents who did not work with male teachers thought that male teachers might be harsh and indifferent, and it was concluded that they had a fear of abuse, but the parents who worked with male teachers did not have such and such fears. This shows that parents who do not work with male teachers approach male preschool teachers with prejudice and prejudice. In order to answer this research question, as a result of the answers taken from the questions asked to the parents, it was concluded that the parents should have the personal characteristics (love of children, patience, soft temperament, interest) and professional characteristics (democracy, professional knowledge, effective classroom management). In line with these results, while the parents who have male teachers in their class gave common answers to the characteristics that a teacher should have, with the parents who do not have a male preschool teacher in their class, in terms of professional characteristics, they did not mention the characteristics of "communication, patience and order" in terms of personal characteristics. As a result of the answers received from the questions asked to the parents in order to answer this research question, the parents who work with male teachers think that male teachers have an effective classroom management.

The parents said that the male preschool teacher was a role model for the children, provided continuity and acted impartially towards the children. Among these parents who work with male teachers, there are those who say that the teacher is insufficient to meet the child's self-care needs, as well as those who say that they can meet their self-care needs. Important data were obtained in this study on parents' perceptions of the effect of gender on preschool teachers. The first of these is that parents who do not work with male preschool teachers think that male preschool teachers do not have any advantage. They said that female teachers are more suitable for this profession. On the contrary, parents working with male preschool teachers emphasized that a teacher should be an educator rather than the gender of the teacher. As a second important result, the parents who do not work with male teachers think that male teachers will be too harsh for pre-schoolers and they will not be able to come down to the level of their children. On the other hand, parents working with male teachers saw this situation as an advantage in effective classroom management and emphasized that male teachers were not harsh and could go down to the level of children.

Another important result is that the parents who do not work with a male teacher in preschool have a fear of abuse, whereas the parents who work with a male teacher do not have such fears. 


\section{REFERENCES}

Cameroon, C. (2001) General Evaluation and Future Recommendations. The Role and Importance of the Father in the Child's Life in the Symposium Report. Istanbul : Mother Child Education Foundation Publication, No:12.

Fagan, J. (1996). Getting Males in Early Childhood Programs.

Kümbetoğlu, B. (2005) Qualitative Method and Research in Sociology and Anthropology, Bağlam Publications, Istanbul.

Lamb, (2001). The Role and Importance of the Father in Child Development with an Intercultural Perspective. The Role and Importance of the Father in the Child's Life in the Symposium Report. Istanbul: Mother Child Education Foundation Publication, No: 12.

McBride, B.A., Rane, T.R., (1997) Father/Male Involmement in Early Childhood Programs: Issues and Challenges. Early Childhood Educations Journal.

Yagbasan, M, Aksoy, G. (2016). Parents' Perspective on Male Kindergarten Teachers (A Field Study in Elazig Province). Turkish journal of Educational Studies. 